TITLE:

\title{
Coprophagy in wild bonobos (Pan paniscus) at Wamba in the Democratic Republic of the Congo: a possibly adaptive strategy?
}

\author{
$\operatorname{AUTHOR(S):~}$ \\ Sakamaki, Tetsuya
}

\section{CITATION:}

Sakamaki, Tetsuya. Coprophagy in wild bonobos (Pan paniscus) at Wamba in the

Democratic Republic of the Congo: a possibly adaptive strategy?. Primates 2010, 51(1): $87-$ 90

ISSUE DATE:

2010-01

URL:

http://hdl.handle.net/2433/123417

RIGHT:

The original publication is available at www.springerlink.com 
1 Coprophagy in wild bonobos (Pan paniscus) at Wamba in the Democratic Republic of

2 the Congo: a possibly adaptive strategy?

3

4 Author's name: Tetsuya Sakamaki

5

6 Affiliation of author: Primate Research Institute, Kyoto University

7 Address of author: Primate Research Institute, Kyoto University, Kanrin 41, Inuyama,

$8 \quad$ Aichi 484-8506, Japan

$9 \quad$ E-mail: sakamaki@pri.kyoto-u.ac.jp

10 Tel: +81-568-63-0541

11 Fax: +81-568-63-0565

12

13 
14 Abstract Four cases of coprophagy and two cases of fecal inspection were 15 identified during the $1,142 \mathrm{~h}$ of observing wild bonobos at Wamba in the Luo 16 Scientific Reserve in the Democratic Republic of the Congo. At least 5 females in the 17 study group practiced coprophagy and/or fecal inspection. According to our daily behavioral observations, boredom and stress, insufficient roughage, and the search for essential nutrients could not explain the coprophagy. Several episodes observed in this study indicated that bonobos might have sought and ingested certain valuable food items, such as hard Dialium seeds, in feces during relatively lean seasons. Although coprophagy occurred only rarely among wild bonobos, this practice appeared to represent a possibly adaptive feeding strategy during periods of food scarcity rather than a behavioral abnormality.

\section{Keywords}

Bonobo, Pan paniscus, Coprophagy, Inspect feces, Adaptive strategy,

Wamba.

\section{Introduction}

Coprophagy refers to the ingestion of one's own (autocoprophagy) or others' (allocoprophagy) fecal material; this practice occurs in wild populations of lagomorphs, rodents, and, to a lesser degree, piglets, foals, dogs, and primates (Soave and Brand 1991; Fish et al. 2007). African apes, gorillas, and chimpanzees practice coprophagy both in captivity and in their natural environments (Harcourt and Stewart 1978; Akers and Schildkraut 1985; Goodall 1986; Hook et al. 2002). Although coprophagy in wild chimpanzees has been seen only rarely, this practice has been observed in several long-term study sites, including those in Gombe, Mahale, Assirik, Fongoli, and Semliki (Nishida et al. 1999; Payne et al. 2008). 
Although the cause of coprophagy in chimpanzees and gorillas remains unclear,

several hypotheses have been proposed. (1) Boredom and stress: In captivity, fewer social stimuli and less time to search for food can cause boredom and stress. Such situations might induce coprophagy or other abnormal behaviors (Akers and Schildkraut 1985; Nash et al. 1999). It has been hypothesized that coprophagy among wild mountain gorillas might be associated with periods of heavy rain because gorillas might need to relieve boredom and/or eat something warm under these circumstances (Harcourt and Stewart 1978). (2) Insufficient roughage: Deficiencies in sources of dietary roughage (e.g., fibrous leaves) can occur in captivity and might increase the frequency of coprophagy (Fritz et al. 1992). (3) Essential nutrients: In some lagomorphs and rodents, coprophagy is apparently an adaptive trait permitting full digestion of complex carbohydrates. It also provide vitamins, minerals, amino acids, and other nutrients (Soave and Brand 1991). Vitamin B12 might be a key reason for engaging in coprophagy among primarily herbivorous apes because it is present only in animal matter (Oxnard 1966). (4) Food scarcity: Chimpanzees at Gombe in Tanzania engaged in coprophagy during the 1981 dry season, a period of fruit scarcity (Goodall 1986). The pressures of foraging in food-scarce environments might induce coprophagy. (5) Reingesting valuable food items such as meat and hard seeds: Hard seeds such as Dialium spp. and Saba comorensis might represent the target in the reingested feces; that is, coprophagy might constitute a potentially efficient way of ingesting the nutritional content of seeds that have already passed through the stomach (Uehara 1979; Goodall 1986; Krief et al. 2004; Payne et al. 2008).

Although coprophagy has been observed among wild bonobos (Pan paniscus) at Wamba and Lomako (ethogram created in a workshop, "Behavior, Ecology and Conservation of Wild Bonobos: Current Activities and Plans for the Future,” Inuyama, Japan, 2003), this is the first report to include details about coprophagy among wild 
66 bonobos. I examined the applicability of the aforementioned hypotheses to my 67 observations.

68

90 I observed four episodes of autocoprophagy (cases 1-4) and two episodes of fecal

\section{Methods}

I studied bonobos in the E1 group at Wamba $\left(0^{\circ} 11^{\prime} 8^{\prime \prime} \mathrm{N}, 22^{\circ} 37^{\prime} 58^{\prime \prime} \mathrm{E}\right)$ in the northern sector of the Luo Reserve in the Democratic Republic of the Congo. All individuals in the group were identified and well habituated. Artificial provisioning was abolished in 1996. The history of the E1 group and the details of the study site have been described by Kano (1992), Furuichi et al. (1998), Hashimoto et al. (2008) and Idani et al. (2008).

Observations were made during three study periods. Period 1: August 11-November 2, 2007; Period 2: January 31-March 11, 2008; Period 3: September 1, 2008-January 4, 2009. I attempted to locate the E1 group during 6 days of each week and to follow the parties from one sleeping site to the next. I recorded ad libitum the behaviors of those bonobos within sight as I followed them. Total observation time was 1,141 h 57 min across 156 days (Table 1). The E1 group was comprised of 23-26 individuals including 9 adult males and 6-7 adult females (15 years or older) during the period under investigation.

In this study, coprophagy refers to feces-eating behavior, irrespective of whether bonobos ate the feces or extracted and ate something selectively, or object of ingestion was not confirmed.

\section{Results} inspection (cases ${ }^{\mathrm{a}} 1$ and 2) (Table 1). Coprophagy occurred 0.35 times per 100 hours. 
92 Four females (2 adults, 1 subadult, and 1 immature bonobo) engaged autocoprophagy.

93 During the episodes of fecal inspection, 2 adult females (one of whom, Sala, practiced

94 coprophagy as well) defecated directly into their own hands, placed the feces close to their faces, and then dropped it without ingesting.

Cases 1 and 2 occurred in October, a month of high fruit availability, including

Discussion 
118 This is the first report on the details of coprophagy among wild bonobos. This study

119 indicated that bonobos only rarely engaged in coprophagy in natural environments.

120 Although we cannot infer the cause of coprophagy on the basis of the data collected in 121 this study, we can rule out certain previous causal hypotheses. Hypothesis 1, boredom 122 and stress: We observed the subjects in their natural habitat, which involved searching 123 for foods and interacting with group members. This environment was no less socially 124 stimulating than is captivity. In addition, boredom during heavy rains could not explain 125 the coprophagy observed in this study because coprophagy occurred outside of the months with the greatest rainfall (September-November; Mulavwa et al. 2008). Being followed by human observers almost all day might have been stressful to the bonobos. However, the bonobos in the E1 group were so accustomed to humans that they did not seem to be unduly stressed by being followed by the observers. Hypothesis 2, lack of dietary roughage: This hypothesis could not explain the coprophagy observed in this study because sources of roughage were almost always available in the habitat; for example, piths/shoots of terrestrial herb vegetation [e.g., Aframomum spp. (Zingiberaceae), Haumania Liebrechtsiana and Megaphrynium macrostachyum (Marantaceae)] and young leaves [e.g., Scorodophloeus zenkeri (Caesalpiniaceae)] were observed (Kano and Mulavwa 1984). Hypothesis 3, essential nutrients: Bonobos in the study group were able to consume essential nutrients such as Vitamin B12 by eating insect larvae, earthworms, vertebrates, and eggs of birds (Kano and Mulavwa 1984). Even if certain nutrients were derived from feces, the concentration of these nutrients in the feces would be insufficient for daily requirements. Further studies are needed to investigate nutrients in foods and feces.

The other hypotheses suggest variables that might have induced coprophagy among the bonobos in this study. Hypothesis 4, food scarcity: Contrary to expectation of this hypothesis, coprophagy observed in cases 1 and 2 occurred when favorite fruit 
144 foods were relatively abundant. However, coprophagy in cases 3 and 4 occurred when

145 fruit was less plentiful and when the bonobos were traveling only a short distance, and

146 therefore, feeding activities were largely limited due to the epidemic of a flu-like

147 disease. Hypothesis 5, reingesting valuable food items such as hard seeds: Rogers et al.

148 (1998) reported that wild gorillas extract and consume Dialium seeds from feces, and

149 Krief et al. (2004) also reported that chimpanzees rehabilitated into a natural

150 environment ingested Dialium seeds extracted from feces. Certain hard seeds in feces,

151 such as Dialium spp., might be items of interest for gorillas and chimpanzees because

152 of their protein content (Krief et al. 2004; Payne et al. 2008). During the season that

153 included coprophagy, cases 1 and 2 and fecal inspection cases ${ }^{\mathrm{a}} 1$ and 2, bonobos primarily ate fruits of the Landolphia spp., the seeds of which are similar to those of

Saba comorensis that chimpanzees crunch and eat (Uehara 1979; Payne et al. 2008).

During the season including cases 3 and 4, bonobos primarily ate fruits of Dialium spp., and a bonobo was observed to extract the seeds in case 4 . In case ${ }^{a} 2$ and case 4 , bonobos rubbed their hands on the stems of a tree/vine probably to clearn their hands after they dropped the feces. These observations suggested that bonobos searched for certain valuable food items in their feces during relatively lean food seasons. Environment Research Fund (F-061 to T. Nishida) of the Japanese Ministry of the Environment. I thank the Research Center for Ecology and Forestry (CREF) of the Democratic Republic of the Congo for permission to conduct the fieldwork in the Luo Scientific Reserve. I am also grateful to N. Mwanza, M. Mulavwa, K. Yangozene, S. Kuroda, H. Takemoto, Y. Tsuji, the research assistants at Wamba, and other members of CREF for their support and cooperation in the field, as well as to T. Nishida, T. Furuichi, and members of the Wamba Committee for Bonobo Research for their 
encouragement and useful comments.

\section{References}

Akers JS, Schildkraut DS (1985) Regurgitation/reingestion and coprophagy in captive gorillas. Zoo Biol 4: 99-109

Fish KD, Sauther ML, Loudon JE, Cuozzo FP (2007) Coprophagy by wild ring-tailed lemurs (Lemur catta) in human-disturbed locations adjacent to the Beza Mahafaly Special Reserve, Madagascar. Am J Primatol 69:713-718

Fritz J, Maki S, Nash LT, Martin T, Matevia M (1992) The relationship between forage material and levels of coprophagy in captive chimpanzees (Pan troglodytes). Zoo Biol 11: 313-318

Furuichi T, Idani G, Ihobe H, Kuroda S, Kitamura K, Mori A, Enomoto T, Okayasu N, Hashimoto C, Kano T (1998) Population dynamics of wild bonobos (Pan paniscus) at Wamba. Int J Primatol 19: 1029-1043

Goodall J (1986) The chimpanzees of Gombe: Patterns of behavior. Harvard University Press, Cambridge.

Harcourt AH, Stewart KJ (1978) Coprophagy by wild mountain gorilla. East Afr Wildl J 16: 223-225

Hashimoto C, Tashiro Y, Hibino E, Mulavwa M, Yangozene K, Furuichi T, Idani G, Takenaka O (2008) Longitudinal structure of a unit-group of bonobos: Male philopatry and possible fusion of unit-groups. In: Furuichi T, Thompson J (eds.) The Bonobos: Behavior, ecology, and conservation. Springer, New York, pp 107-119

Hook MA, Lambeth SP, Perlman JE, Stavisky R, Bloomsmith MA, Schapiro SJ (2002) Inter-group variation in abnormal behavior in chimpanzees (Pan troglodytes) and 
rhesus macaques (Macaca mulatta). Appl Anim Behav Sci 76: 165-176

Idani G, Mwanza N, Ihobe H, Hashimoto C, Tashiro Y, Furuichi T (2008) Changes in the status of bonobos, their habitat, and the situation of humans at Wamba in the Luo Scientific Reserve, Democratic Republic of Congo. In: Furuichi T, Thompson J (eds.) The Bonobos: Behavior, ecology, and conservation. Springer, New York, pp 291-302

Kano T (1992) The Last Ape: Pigmy Chimpanzee Behavior and Ecology. Stanford Univ Press, Stanford.

Kano T, Mulavwa M (1984) Feeding ecology of the pygmy chimpanzees (Pan paniscus) of Wamba. In: Susman RL (ed) The Pygmy Chimpanzee. Plenum Publishing Corporation, pp. 233-274

Krief S, Jamart A, Hladik CM (2004) On the possible adaptive value of coprophagy in free-ranging chimpanzees. Primates 45: 141-145

Mulavwa M, Furuichi T, Yangozene K, Yamba-Yamba M, Motema-Salo B, Idani G, Ihobe H, Hashimoto C, Tashiro Y, Mwanza N (2008) Seasonal change in fruit production and party size of bonobos at Wamba. In: Furuichi T, Thompson J (eds.) The Bonobos: Behavior, ecology, and conservation. Springer, New York, pp 121-134

Nash LT, Fritz J, Alford PA, Brent L (1999) Variables influencing the origins of diverse abnormal behaviors in a large sample of captive chimpanzees (Pan troglodytes). Am J Primatol 48: 15-29

Nishida T, Kano T, Goodall J, McGrew WC, Nakamura M (1999) Ethogram and ethnography of Mahale chimpanzees. Anthropol Sci 107: 141-188

Oxnard CE (1966) Vitamin B12 nutrition in some primates in captivity. Folia Primatol 4: 424-431

Payne CLR, Webster TH, Hunt KD (2008) Coprophagy by the semi-habituated 
223 Rogers ME, Voysey BC, Mcdonald KE, Parnell RJ, Tutin CEG (1998) Lowland gorillas and seed dispersal: The importance of nest sites. Am J Primatol 45: 45-68

Sakamaki T, Mulavwa M, Furuichi T (2009) Flu-like Epidemics in Wild Bonobos (Pan paniscus) at Wamba, the Luo Scientific Reserve, Democratic Republic of Congo. Pan Afr News 16: 1-4

229 Soave O, Brand CD (1991) Coprophagy in animals: A review. Cornell Vet 81: 357-64

230

Uehara S (1979) The chimpanzees of Kasoge K group [in Japanese]. Monkey 170: 
Table 1. Observations of coprophagy

\begin{tabular}{|c|c|c|c|c|c|}
\hline \multirow[t]{2}{*}{ Month and Year } & \multicolumn{2}{|c|}{ Observation } & \multicolumn{3}{|c|}{ Observation of coprophagy } \\
\hline & No. days & Time & & & \\
\hline \multicolumn{6}{|l|}{$\begin{array}{l}\text { Period } 1 \\
\end{array}$} \\
\hline August 2007 & 10 & 61 h 57 min & None & - & - \\
\hline September 2007 & 21 & 137 h 9 min & None & - & - \\
\hline October 2007 & 22 & $157 \mathrm{~h} 10 \mathrm{~min}$ & Case 1 (Oct 31) & $\begin{array}{l}\text { Sala } \\
\text { (adult female) }\end{array}$ & $\begin{array}{l}\text { At } 0921 \mathrm{~h} \text {, she took her feces in her left hand and ate it. She again took her feces in her } \\
\text { left hand and ate it. The feces seemed to be dark in color and hard. }\end{array}$ \\
\hline November 2007 & 2 & $13 \mathrm{~h} 10 \mathrm{~min}$ & None & - & - \\
\hline \multicolumn{6}{|l|}{ Period 2} \\
\hline January 2008 & 1 & 10 h 58 min & None & - & - \\
\hline February 2008 & 17 & $119 \mathrm{~h} 47 \mathrm{~min}$ & None & - & - \\
\hline March 2008 & 7 & 66 h 58 min & None & - & - \\
\hline \multicolumn{6}{|l|}{ Period 3} \\
\hline September 2008 & 22 & 151 h 7 min & Case $^{\mathrm{a}} 1$ (Sep 24) & $\begin{array}{l}\text { Sala } \\
\text { (adult female) }\end{array}$ & $\begin{array}{l}\text { At } 0821 \mathrm{~h} \text {, she evacuated a small amount of feces, which fell on the ground. She held } \\
\text { the fecal material that emerged second in her left hand, moved it close to her face, } \\
\text { looked at it carefully, and then dropped it. }\end{array}$ \\
\hline \multirow[t]{2}{*}{ October 2008} & 19 & 148 h 6 min & Case $^{\mathrm{a}} 2$ (Oct 10) & $\begin{array}{l}\text { Hoshi } \\
\text { (adult female) }\end{array}$ & $\begin{array}{l}\text { At } 1003 \mathrm{~h} \text {, she held her feces in her right hand after appearing to experience some } \\
\text { difficulty with the excretory process, moved it close to her face and looked at it, and } \\
\text { then dropped it. Next, she rubbed her right hand on a woody vine. }\end{array}$ \\
\hline & & & Case 2 (Oct 10) & $\begin{array}{l}\text { Jacky } \\
\text { (adult female) }\end{array}$ & $\begin{array}{l}\text { At } 1439 \mathrm{~h} \text {, her feces fell between her fingers even though she positioned her hand close } \\
\text { to her anus. She held the second feces in her left hand, moved it close to her face, } \\
\text { looked at it, and then ate it. }\end{array}$ \\
\hline November 2008 & 8 & 59 h 16 min & None & - & - \\
\hline \multirow[t]{2}{*}{ December 2008} & 25 & 211 h 43 min & Case 3 (Dec 5) & $\begin{array}{l}\text { Nachi } \\
(2 \text {-year-old } \\
\text { female) }\end{array}$ & $\begin{array}{l}\text { At } 0620 \text { h, she grasped her feces in her right hand and ate it. The feces were about } 5 \\
\mathrm{~cm} \text { long and seemed to be light in color. }\end{array}$ \\
\hline & & & Case 4 (Dec 10) & $\begin{array}{l}\text { Fuku } \\
\text { (approximately 10- } \\
\text { year-old female) }\end{array}$ & $\begin{array}{l}\text { At } 0731 \mathrm{~h} \text {, she grasped her feces in her left hand. At } 0732 \mathrm{~h} \text {, she moved it close to her } \\
\text { face and looked at it. At } 0735 \mathrm{~h} \text {, she ate it and dropped something that resembled seeds } \\
\text { from her mouth. At } 0736 \mathrm{~h} \text {, she rubbed the palm of her left hand on a tree trunk. At } \\
0741 \mathrm{~h} \text {, she kept the feces in her hand while crunching seeds in her mouth. She used } \\
\text { her lips to select only seeds from the feces, and chewed them in her mouth. She } \\
\text { dropped other fibers or material from the feces. At } 0747 \mathrm{~h} \text {, she finished eating the feces } \\
\text { and rubbed her left hand on a tree trunk. The feces seemed to be ocherous in color. }\end{array}$ \\
\hline January 2009 & 2 & $4 \mathrm{~h} 36 \mathrm{~min}$ & None & - & - \\
\hline Total & 156 & 1141 h 57 min & & & \\
\hline
\end{tabular}

